\title{
Lenin in Barcelona: the Russian Revolution and the Spanish trienio bolchevista, 1917-1920
}

\section{Arturo Zoffmann Rodriguez}

In 1916, Belgian-born writer and revolutionary Victor Serge found himself in Spain. The son of Russian exiles, Serge began as an anarcho-syndicalist but would eventually come to embrace Marxism under the influence of the Russian Revolution. Escaping political persecution in his adoptive France, he crossed the Pyrenees into Catalonia and immediately got involved in the syndicalist movement of Barcelona. The news of the fall of the Tsar in March further electrified an already effervescent labor movement. In his memoirs Serge recalled:

\begin{abstract}
The Spaniards, even the workers on the shop floor beside me, who were no militants, instinctively understood the Petrograd days, since their imagination transposed those events to Madrid and Barcelona. The monarchy of Alfonso XIII was no more popular or stable than that of Nicholas II. The revolutionary tradition of Spain, like that of Russia, went back to the time of Bakunin. Similar social causes were operating in both countries: agrarian problems, retarded industrialization, a political regime at least a century and a half behind Western Europe. ${ }^{1}$
\end{abstract}

These comparisons between Spain and Russia were not uncommon. Lev Trotskii, who also spent part of the First World War in Spain, is credited with having referred to Spain as "the country that, after Russia, is most hospitable to Bolshevik propaganda." ${ }^{2}$ In 1921, after having visited Moscow, Spanish syndicalist leader Joaquín Maurín claimed that "there is no country as similar to Russia as Spain. That means that we have the duty ... of being the second ones to hoist the red flag of proletarian emancipation." ${ }^{3}$ Liberal philosopher José Ortega y Gasset referred to the Spaniards and the Russians as the two pueblo races of Europe, two impulsive and indomitable nations that were innately prone to rebellion. ${ }^{4}$ The authorities were also aware of the parallels between Spain and Russia. An anonymous report from 1919 found in Spanish Prime Minister Count of Romanones' archive observed that "the Spanish proletariat is very similar to the Russian, for their mentality and their love for dazzling things and for grandiose phraseology." 5

On opposite sides of the European continent, Bourbon Spain and Romanov Russia were characterized by their backwardness and underdevelopment. In both countries, an increasingly restless labor movement, a landhungry peasantry, and daunting national and colonial questions combined

1. Victor Serge, Memoirs of a Revolutionary, 1901-1941 (Oxford, 1980), 53-54.

2. Tomás Elorrieta y Artaza, El movimiento bolchevista (Madrid, 1919), 33.

3. Joaquín Maurín, El Sindicalismo a la luz de la Revolución Rusa (Lleida, 1922), 108.

4. José Ortega y Gasset, Invertebrate Spain, trans. M. Adams (New York, 1937), 71.

5. Real Academia de la Historia, Fondo Romanones, box 96, file 34. Cited in: Mikel Aizpuru, "La expulsión refugiados desde España en 1919: Exiliados rusos y de otros países,” Migraciones y exilios 11 (2010): 112. 
into an explosive Gordian knot. The structural similarities between both societies were dramatically confirmed by the sweeping social revolutions the two countries underwent in the first decades of the twentieth century: 1917 and 1936 stand at the apex of modern European revolutions. The start of the Russian Revolution helped to trigger a process of extreme militancy in the Spanish labor movement, the trienio bolchevista ("three Bolshevik years"). In the words of contemporary observer Juan Díaz del Moral, Spanish workers and peasants "reversed the balance of forces between capital and labor, and in some towns they exercised a dictatorship of the proletariat of sorts." "For all this," he pithily noted, "only one word had been necessary: Russia."

The social and political polarization of Spanish society mirrored, and was stimulated, by developments in the rest of Europe. The revolutions in Germany, Austria-Hungary, and, above all, in Russia became models in the eyes of Spanish revolutionaries. Conversely, Bolshevism became a specter that haunted the Spanish propertied classes and drove them towards an authoritarian solution to the country's problems, following the path of Hungary and Italy. ${ }^{7}$ In September 1923, General Primo de Rivera staged a military coup d'état with widespread support from the ruling elites. Although this turbulent period in Spanish history did not culminate in social revolution but in rightwing dictatorship, it opened the cracks along which Spanish society would fracture in the 1930s, very much as the 1905 Russian Revolution prepared the ground for 1917. The national question, the land question, the inefficiency and corruption of the Spanish state, and, above all, the militancy of the labor movement, all came to surface with force in these years, generating political polarization and violence and short-circuiting the perspectives for democratic reform.

There is a substantial corpus of literature in English and Spanish on the trienio bolchevista, although it has tended to allude to the impact of the Russian Revolution cursorily, in broader studies with a national slant on Spain's political and social history. ${ }^{8}$ This paper will provide a synopsis of the events of this period and evaluate their ulterior significance, and above all will assess the specific impact of the Russian Revolution in the country.

The agitations kindled by the Russian Revolution in Spain had two phases. Before the worker and peasant risings that characterized this period, there was a brief but intense liberal apogee, stimulated by the February Revolution.

6. Juan Díaz Del Moral, Historia de las agitaciones campesinas andaluzas Córdoba: Antecedentes para una reforma agraria (Madrid, 1973), 269.

7. Francisco J. Romero Salvadó and Angel Smith, "The Agony of Spanish Liberalism and the Origins of Dictatorship: A European Framework,” in Francisco J. Romero Salvadó and Angel Smith, eds., The Agony of Spanish Liberalism: From Revolution to Dictatorship, 1917-1923 (New York, 2010), 1-2.

8. In English, see: Gerald H. Meaker, The Revolutionary Left in Spain, 1914-1923 (Stanford, 1974); Francisco J. Romero Salvadó, Spain 1914-1918: Between War and Revolution (London, 1999); Francisco J. Romero Salvadó, The Foundations of Civil War: Revolution, Social Conflict and Reaction in Liberal Spain, 1916-1923 (London, 2008); Romero Salvadó and Smith, The Agony of Spanish Liberalism. In Spanish: Juan Avilés Farré, La fe que vino de Rusia: La revolución bolchevique y los españoles, 1917-1931 (Madrid, 1999); Juan Antonio Lacomba, La crisis Española de 1917 (Madrid, 1970); Carlos Forcadell, Parlamentarismo y bolchevización: El movimiento obrero español, 1914-1918 (Barcelona, 1978). 
Public opinion in neutral Spain had been divided over the question of the war. On the one hand, stood the germanófilos, those sympathetic towards the Central Powers, who tended to represent the most conservative sectors of Spanish society. On the other hand were proponents of Aliadofilia, support for the Allies, which was typical of liberals and republicans. The reformist PSOE (Spanish Socialist Workers' Party), the Spanish section of the Second International, also backed the Allies, while the powerful anarcho-syndicalist movement was bitterly hostile to both camps. ${ }^{9}$

The cause of the aliadófilos had been embarrassed by the presence of autocratic Russia in the Allied camp. The overthrow of the Tsar, however, putatively made the Entente wholly democratic, and redoubled their commitment to enter the war on the side of the Allies. The intervention of Woodrow Wilson's America in the war further enhanced the Allied cause. Moreover, the wartime hike in demand for Spanish exports had bolstered Spanish industry, mostly concentrated in Catalonia. This emboldened the Spanish (and particularly the Catalan) industrial bourgeoisie, which had historically been pitted against the politically influential landowning and bureaucratic elites. In the spring of 1917, the regime was rocked by the mutiny of disgruntled army officers. Conditions seemed ripe for an ambitious campaign for liberal reform, and in the eyes of some, to press for Spanish intervention in the war. ${ }^{10}$

The Spanish "liberal moment" reached its zenith in the summer of 1917, when Catalan regional politician Francesc Cambó, closely aligned with the Barcelonese bourgeoisie, organized an assembly of rebellious parliamentarians. As in Russia, however, the quest for liberal transformation was undercut by the rising tide of class conflict. Cambó and his allies had entered into negotiations with the leaders of the socialist unions to second his call for a constituent assembly with a general strike. The anarcho-syndicalists also became involved in the movement. Cambó, however, feeling the groundswell of working-class radicalization, decided to backtrack. The news of the February Revolution had also exhilarated the labor movement. The strike took place in August 1917, and the ferocity of the struggle in some regions was such that it clouded the ambitions of the liberal reformers. The liberal alliance with the labor movement was broken. The fate of the Russian provisional government substantiated the impression that the "social question" was far more dangerous than the corruption, authoritarianism, and backwardness of the Spanish state. Cambó resolved that, before the danger of Bolshevism, "the question of liberty had to be put off for some time."11

The years 1918-20 saw unprecedented levels of working-class and peasant agitation. The defeat of the 1917 general strike momentarily weakened the urban labor movement, but at this point waves of peasant insurrections swept across southern Spain. Sharecroppers and farmhands went on strike; manor houses were torched; crops were burned, farming utensils destroyed, and cattle killed. Some villages were occupied by rebellious peasants, who declared

9. Romero Salvadó, Spain 1914-1918.

10. Francisco J. Romero Salvadó, "Spain’s Revolutionary Crisis of 1917: A Reckless Gamble," in The Agony of Spanish Liberalism, 64-65.

11. Francesc Cambó, Memòries (1876-1936) (Barcelona, 1981), 329. 
anarchy. The peasant rebellions were only subdued after a 20,000-strong army was dispatched in Andalusia in the spring of $1919 .{ }^{12}$ However, when the rural tumults subsided the movement of the industrial workers made a vigorous comeback, particularly in Catalonia. In the spring of 1919 a dispute in a Barcelona power plant spiraled into a citywide general strike that "paralyzed everything."13 In 1918, 463 strikes took place in Spain; in 1919, 895; and in $1920,1,060 .^{14}$

The outlook of Spanish liberalism became increasingly somber, and bourgeois democrats sided with the old elites in the struggle against labor. The propertied classes, of both liberal and conservative persuasions, were gripped by a hysteric Red Scare. Wild exaggerations about the Bolshevik threat were propagated in the bourgeois press. At one point, it was reported that Vladimir Lenin had landed in Barcelona to lead the Spanish revolution. ${ }^{15}$ The government, fearing all things Russian, made plans to deport the bulk of Russian citizens from Spain. ${ }^{16}$ Virulent repression was unleashed against the labor movement, with the blessing of important sectors of liberal opinion. In Catalonia, the heart of the agitations of the trienio bolchevista, paramilitary groups were armed by the bosses and thrown against the syndicalists. Anarchist Gastón Leval described the repressions of these years in dramatic terms: "In Barcelona, the repression against the libertarian labor movement continued to strike with the same savage intensity. The arrests were daily, jails full to the brim, prisoners were deported on foot to other provinces, the gangs of mercenaries ... set up by the bosses, killed our militants."17

This process culminated in the military coup of Primo de Rivera in September 1923, which inaugurated a six-year praetorian dictatorship. As Angel Smith has explained, the coup was actively supported by Catalan liberal industrialists, and was hatched in the villas of the Barcelonese bourgeoisie. ${ }^{18}$

The Spanish labor movement was divided into two tendencies. On the one hand stood the PSOE (Spanish Socialist Workers' Party), a moderate socialist party in the Social Democratic tradition, which was dominant in the bureaucratic capital of Madrid, the Castilles, and in the industrial areas of the north. The other proletarian force in Spain was the anarcho-syndicalist movement, organized after 1910 under the banners of the CNT (National Confederation of Labor). The anarcho-syndicalists were influential among the peasantry of

12. Francisco Cobo Romero, “The 'Red Dawn' of the Andalusian Countryside: Peasant Protest during the 'Bolshevik Triennium,' 1918-20,” in The Agony of Spanish Liberalism, 131-35.

13. Ángel Pestaña, Conferencia sindicalista dada por Angel Pestaña en el Teatro de la Comedia de Madrid el día 23 de Octubre de 1919 y organizado por el Ateneo Sindicalista (Madrid, 1919), 16.

14. Santiago Castillo, ed., Historia de la Unión General de Trabajadores, 2 vols. (Madrid, 1998), 2:72-74.

15. "Los extranjeros en Barcelona,” El Sol, Thursday 16, January, 1919, 6.

16. Manuel Aznar, “El frente policíaco español,” El Sol, Thursday 16, January, 1919, 1.

17. Gaston Leval, "Mémoires," Gaston Leval Papers, International Institute of Social History (Amsterdam), 141. Summary available at https://search.socialhistory.org/Record/ ARCH00815 (last accessed July 13, 2017).

18. Angel Smith, "The Lliga Regionalista and the Catalan Right and the Making of the Primo de Rivera Dictatorship, 1916-23," in The Agony of Spanish Liberalism, 163-67. 
Aragon, Valencia, Andalusia, and Extremadura, and most importantly, they were predominant in industrial Catalonia. The years 1917-20 were a time of vigorous growth for the libertarians, while the socialists languished. ${ }^{19}$ This process was closely connected with the impact of the Russian Revolution in Spain.

It is unsurprising that the socialist leadership reacted to the October Revolution with unease and apprehension. The news of the Bolshevik rising came at a difficult time for the socialists. They had put themselves at the forefront of the general strike of August 1917, and had assumed responsibility for the defeat. The failure of the strike strengthened the legalist tendencies in the party, which became weary of revolutionary adventures. When the socialists heard of the October Revolution, their immediate reaction was silence. While the anarcho-syndicalist press celebrated the revolution, the socialists refused to report on it. ${ }^{20}$ An elderly and bedridden Pablo Iglesias, historic leader of the PSOE, referred to the event as "tragic" and "inopportune."21 The reasons for this silence are not hard to surmise. The reformist party leadership was visibly hostile toward the Bolsheviks, but it did not dare to come out publicly against the Soviet regime for fear of the militancy among the rank-and-file. ${ }^{22}$ It therefore lapsed into immobility, attempting to hold out until the wave of enthusiasm died down. It drew out the debates on the Russian question, bidding for a "conditional" affiliation to the Third International (which was later recanted), and benefitting from a series of inauspicious pro-Soviet splits. ${ }^{23}$

The story of the Spanish anarcho-syndicalists in these years is very different. They filled the vacuum left by the socialists and grew impressively. The CNT boasted almost 800,000 members in December 1919. The libertarians led the labor movement in the regions that were at the center of the turbulences in this period, Andalusia and Catalonia. To a large extent, their success was related to their capacity to associate themselves with the Russian Revolution. Indeed, the Spanish Bakuninists went through a brief but intense honeymoon with the Russian Marxists.

The prestigious anarcho-syndicalist weekly Tierra y Libertad welcomed the revolution in raptures in a front-page article. "The old world has started to fall apart in Russia, and it will soon collapse everywhere, because examples are contagious and the Russian success emboldens us." ${ }^{24}$ This ebullience was present in most of the anarcho-syndicalist press. As contemporary observer Díaz del Moral noted, in the wake of the Bolshevik uprising it was difficult to find a libertarian publication "that did not fill its columns with news and fervent panegyrics about the great revolution.. ${ }^{25}$ Del Moral has left an invaluable

19. In the Hispanic world, the terms "libertarian" and "anarchist" are synonymous.

20. Forcadell, Parlamentarismo y bolchevización, 241-50.

21. Chris Ealham, “An Impossible Unity: Revolution, Reform and Counter-Revolution and the Spanish Left, 1917-23," in The Agony of Spanish Liberalism, 95.

22. Ibid., 95.

23. Joaquín Maurín, El Bloque Obrero y Campesino: Origen, actividad, perspectivas (Barcelona, 1932), 4-9.

24. "De la revolución rusa: la sociedad vieja se hunde," Tierra y Libertad November 21, 1917, 1.

25. Del Moral, Historia, 267. 
account of the expectations awakened among the Andalusian peasantry by the news coming from the east:

In my frequent encounters with workers, I could notice their heightened enthusiasm. All conversations inevitably moved onto the Russian question. If we were talking about farming, immediately someone would ask: What is sowed in Russia? Does it rain a lot there? If we were talking about the weather, the question would be asked: Is it cold or hot in Russia? Is it very far away? Or, in any other context: Where exactly is Russia? How long would it take to walk there on foot? Russia was an obsession that would never leave people's mouths. ${ }^{26}$

Although some veterans of the syndicalist movement such as Salvador Seguí or Eleuterio Quintanilla remained somewhat skeptical of the Soviet regime, enthusiasm for the Bolsheviks was not restricted to the rank-andfile, as was largely the case in the socialist party, but even infected seasoned anarcho-syndicalist cadres. As CNT leader Manuel Buenacasa put it, "who in Spain, being an anarchist, did not call himself a Bolshevik?"27 In its national congress of December 1919, the CNT decided to affiliate with the Third International.

The blurriness of the news coming from Russia undoubtedly facilitated this collusion with the Bolsheviks. Reports on the situation in Russia were contradictory and rumors abounded. The exact ideology of Lenin's party was at first unclear to the anarcho-syndicalists. Although it soon became apparent that they were not anarchists but socialists, their socialism was visibly different from the reformist socialism of the PSOE. The mistranslation of the term Bolshevik as maximalista and Menshevik as minimalista further muddied the waters. "The Russian maximalists (the bolcheviqui)," commented Tierra y Libertad, "form a party of millions of anarchists, although in reality not all of them are anarchists, there are also some socialists ... who are truly revolutionary."28 Many extrapolated the traditional division in Spanish labor politics, and saw the Bolsheviks as the Russian equivalent of the Spanish anarcho-syndicalists, and the Mensheviks as the counterparts of the PSOE. Moreover, Russia was the homeland of Mikhail Bakunin and Petr Kropotkin, and this strengthened the mental association between Bolshevism and anarchism. ${ }^{29}$ The overthrow of the Kerensky, a "dictator in a Phrygian cap," was particularly meaningful to the anarcho-syndicalists after the August strike, where liberals and moderate socialists had been seen to betray the movement. ${ }^{30}$

The anarcho-syndicalists rapidly became aware that the Russian communists had not destroyed the state and done away with all authority, as Bakunin had preached, but had created a new revolutionary regime. Most Spanish anarcho-syndicalists came to embrace the Bolshevik dictatorship of the proletariat, however. Although the polemic over the dictatorship had been

26. Ibid., 82-83.

27. Manuel Buenacasa, El movimiento obrero español, 1886-1926 (Barcelona, 1928), 64.

28. “Los maximalistas y la prensa burguesa," Tierra y Libertad, December 5, $1917,2$.

29. Rudolf Rocker, Revolución y regresión (1918-1951): continuación de la Juventud de un rebelde (1873-1895) y En la borrasca (1895-1918) (Buenos Aires, 1952), 143.

30. “A los canallas de la pluma,” Tierra y Libertad, November 28, 1917, 1. 
one of the bones of contention in the split between Marx and Bakunin in the 1870s, in Spain in 1917 this question had largely faded away. The Spanish Marxists had dropped the notion of the dictatorship of the proletariat, and most debates between anarcho-syndicalists and socialists revolved around questions of reformism and parliamentary participation. Therefore, when the Russian communists resurrected the term, many Spanish anarcho-syndicalists were not immediately hostile to it. As CNT activist Francisco Jordán commented in 1921: "Karl Marx was the first to have preconized the dictatorship of the proletariat, but this idea was forgotten by his disciples, who, quite on the contrary, were always in favor of legality and were hostile to the violent transformation of society. The Third International has the honor of having dusted off this "text"! 31

Moreover, the need for a workers' dictatorship seemed to be vindicated by the ferocity of counterrevolution in Russia, mirrored by the violent repression faced by the anarcho-syndicalists in Spain. Tierra y Libertad announced that the establishment of genuine anarchy "will require a long revolutionary period of several years in which the anarchists will have to become the Authority and act as bosses to ensure the triumph of the revolution." ${ }^{32}$ One of the draft theses of the 1919 national congress of the CNT openly endorsed the dictatorship of the proletariat: "The Russian Revolution, in principle, incarnates the ideals of revolutionary syndicalism. It abolished class and caste privileges giving power to the proletariat ... implanting a transitional proletarian dictatorship to ensure the conquest of the revolution. This gathering declares: That the Second Congress of the CNT should unconditionally unite with the Russian Revolution." 33

The anarcho-syndicalists' infatuation with the Bolsheviks was passionate but short lived. By 1921, the CNT began to turn against the Soviet regime. In June 1922, the confederation disaffiliated from the Third International. The reasons for this turn against the Russian Revolution are manifold. Critical reports about the authoritarianism of the Bolsheviks, and especially their treatment of the Russian anarchists, made their way to Spain in 1920-21. Syndicalist organizations were visibly marginalized in the Third International. The damning account published 1921 by Ángel Pestaña, the first CNT delegate to Soviet Russia, left a deep impression. Importantly, these accounts were arriving at a time of exhaustion and defeat for the Spanish labor movement, which dissipated the heedless optimism of previous years. The emergence of Moscow-sponsored communist parties competing for the same constituency as the anarcho-syndicalists increased tensions between libertarians and Bolsheviks.

The honeymoon between the Spanish anarcho-syndicalists and the Russian Bolsheviks is significant, however. It reflected the expectations awakened by the Russian Revolution among very different constituencies, not simply among the left-wing tendencies in Social Democracy. It also points to

31. Francisco Jordán, La dictadura del proletariado (Mexico, 1922), 5.

32. "Revolución y Anarquía," Tierra y Libertad, December 26, 1917, 1.

33. Memoria del congreso de la Confederación Nacional del Trabajo, celebrado en el Teatro de la Comedia de Madrid, los dias 10 al 18 de Diciembre de 1919 (Barcelona, 1932), 341. 
the mutability of ideas and political identities in these turbulent years of revolution and counterrevolution, and to how the images coming from Russia were reworked and adapted to local conditions. Indeed, the fact that the Bakuninist CNT proved more hospitable to the ideas of the Bolsheviks than the Marxist PSOE strikingly reflects the fluidity of ideologies in these years, and suggests that the temperament of political movements, whether they were radical or moderate, was more important in shaping attitudes towards the Soviet regime than formal ideological identifications.

The Russian Revolution provided an enormous impetus to social conflict in Spain, spurring both revolution from below and counterrevolution from above. Open revolution and civil war were averted in this period, which culminated in a military dictatorship. However, the years 1917-20 foreshadowed the violence of 1936-39. If the 1905 revolution was the "dress rehearsal" of 1917, then one could well conclude that the trienio bolchevista of 1917-20 was the dress rehearsal of the Spanish 1936. 